\title{
Life Cycle Assessment and Feasibility Study of Small Wind Power in Thailand
}




\section{Abstract}

The Thai government's implementation of its 10 year renewable energy plan was done to help increase energy independence and reduce emissions resulting from energy production. Due to Thailand's wind regime, wind turbines which can operate in low wind speeds will be needed to meet this goal. Small wind turbines typically operate at higher efficiency in lower winds, and thus they might prove to be a good option for wind power production in Thailand. Incorporating small wind turbines into power production can be difficult because of the perception of high investment costs and because their net benefit has not been adequately studied. Using a functional unit of producing $50 \mathrm{kWh}$ per month for 10 years we conducted a Life Cycle Assessment comparing the global warming potential (GWP), embodied energy (EE), and levelized cost of electricity (LCOE) of four small wind turbines ( $\leq 20$ kW), a diesel generator, and the Thai Grid. When analyzing GWP of the turbines it was found that they had a lower overall GWP than the diesel generator when in areas with reasonable wind resources. The same is true for embodied energy. Interestingly, in most available wind speed categories in Thailand the LCOE for wind turbines was lower than for the diesel generator. However, neither could compare to the LCOE of the Thai Grid, except in the areas with the highest average wind speeds $(7.0-9.4 \mathrm{~m} / \mathrm{s})$. With this in mind, it is clear that the most important factor when considering wind power generation is the wind regime available in an area. Because of the increased cost relative to the Thai grid, implementation of wind turbines in Thailand was not found to be economically viable. This could be changed given lower costs for turbines and/or government incentives

\section{Introduction}

The Thai government's green energy objectives for 2021 include an ambitious goal of harvesting at least $1200 \mathrm{MW}$ of energy from the wind. At present, Thailand receives less than $8 \mathrm{MW}$ of electricity from wind power (DEDE, 2011). The majority of Thailand has low average wind speeds, meaning that multi-megawatt installations of large wind turbines like those in countries like the United States will not be feasible. For this reason, we seek to investigate the feasibility of small wind turbines for application in Thailand. We will accomplish this goal using Life Cycle Assessment (LCA) framework to compare the embodied energy, global warming potential (GWP), and economic viability of several small wind turbines. We will compare our findings to already established practices of grid electricity use and small diesel generator use for household electricity.

It is our belief that small wind turbines will have to be effectively utilized in Thailand in order to meet the goal of $1200 \mathrm{MW}$ of installed capacity by 2021 . Because of the relatively modest power rating of small wind turbines $(\leq 20 \mathrm{~kW})$ compared with the energy consumption of the average urban household in Thailand (over 800kWh per month), we have chosen to focus on rural households ( $69 \mathrm{kWh}$ per month). In rural areas a small wind turbine has the potential to supply a significant portion of the electricity demand of the average household. Depending on the wind resource available in that area, it is possible to even exceed this electricity demand. 
Means of personal or small community scale electric power production are valuable tools for ensuring the energy security of a rural household or community. Diesel generators have been used in Thailand for many years, and are an established and reliable means of electricity production in rural communities. The Thai government's goal of $25 \%$ renewable energy production by 2021 is an ambitious stab at reduction of dependence on non-domestic energy sources as well as reduction of the environmental burdens associated with Thailand's energy production.

Personal or small community electricity production from clean energy sources like wind and solar could prove to be valuable means to accomplish Thailand's goals for renewable energy production, and if implemented correctly might be able to further increase the energy security of rural areas beyond the capabilities of diesel generators. We seek to investigate the economic feasibility of this possibility with this study. In terms of energy security, solar and wind power have an advantage over diesel electricity generation because they do not require the input of fuel. Likewise, wind power has several characteristics that grant it notable advantages over photovoltaic solar panels in Thailand. Firstly, wind turbines are fully productive in cloudy conditions. This is an important feature during the monsoon seasons, when rain clouds could potentially disrupt proper functioning of solar panels frequently. Similarly, wind turbines only need to be placed in an area where they will receive the most consistent wind possible. Solar panels must be oriented toward the south (in the northern hemisphere) in areas with little to no shade from trees and take up a fairly large amount of area.

The most important factors for determining the viability of the use of small wind turbines as a means to accomplish the goals of energy security, clean power production, and economic feasibility are the available wind resource in any particular region, the environmental burdens and energy requirements associated with the turbine assembly's life cycle, and the cost of the turbine assembly. These factors will be addressed in detail throughout our report.

\section{Goal}

The goal of this study is to assess the lifecycle global warming impacts and embodied energy of four small wind turbines with power ratings of $400 \mathrm{~W}, 2.5 \mathrm{~kW}, 5 \mathrm{~kW}$, and $20 \mathrm{~kW}$. Using information published by DEDE regarding the average wind speed in ten wind classes in Thailand we assess the amount of energy that could potentially be produced by each of the turbines in various areas of the country. From this analysis we compare GWP and embodied energy of the turbines to that of the diesel generator, in addition to comparing the GWP of the Thai grid mix. We also compare the levelized cost of electricity (LCOE) from each of the turbines, the diesel generator, and the Thai grid mix. From this comparison we assess the 
feasibility of a rural household or community investing in any of these small wind turbines as their primary means of electricity production.

\section{Scope}

The functional unit for our LCA is 50kWh of electricity per month for ten years, taking into account the efficiencies of the turbine/generator, the inverter, and the storage batteries. The geographical limitations of this study are limited to Thailand because of the modest wind resource and the current grid mix. The temporal limitations only extend as far as the end of our functional unit, assuming stable costs for electricity from the Thai grid and for diesel fuel.

Our LCA assesses the embodied energy and GWP of the life cycles of the various wind turbines from extraction of raw materials, through processing and refining, transportation, manufacture, operation, maintenance, and finally disposal. Estimates for expected energy output from the four turbines were calculated by two separate methodologies: the power curve method and the swept area method. These expected outputs are then compared to the embodied energy in order to determine the energy payback period, or the amount of time that the turbine will have to operate while producing an assumed average energy output in order to have produced as much energy as was required to produce the assembly. Similar calculations were performed for the diesel generator system.

The wind system in this study was composed of a wind turbine, an inverter, and batteries, and in some cases, a turbine tower. Four wind turbines were analyzed in the study, the Air X 400, the Wes5 Tulipo, the Endurance S-343, and the Jacobs 31-20 with rated power outputs of $400 \mathrm{~W}, 2.5 \mathrm{~kW}, 5 \mathrm{~kW}$, and $20 \mathrm{~kW}$, respectively. These turbines were selected because they represent a range of power outputs that are still considered to be within the small turbine range. Furthermore, a reasonable amount of background data was available for each turbine.

The diesel generator system consists of the generator, diesel fuel, and a battery bank. The fuel tank was excluded because the impacts associated with the fuel tank were considered negligible. Additionally, the inverter was not included because diesel generators generally output alternating current. Generator sizing and fuel consumption were based on average data of similarly sized generators that are of the correct size to fulfill the functional unit.

GWP was calculated using the Institute for Environmental Sciences (CML) methodology. Embodied energy was calculated from "Inventory of Carbon and Energy" published by the University of Bath (Hammond and Jones, 2008). The cost of electricity in Thailand and the grid mix were taken from "The Annual Report: Electric Power in Thailand 2011" (DEDE, 2011). This study could be useful for policy makers and concerned consumers who are interested in investigating how wind power can best be implemented in Thailand. This study is not 
applicable to other nations in Southeast Asia, but our methodology could easily be adapted to any other country interested in assessing wind turbine feasibility.

\section{Inventory Assessment}

Inventory data for the four turbines studied in this report were obtained from previously conducted wind power LCAs (Fleck and Huot, 2009; Kabir et al., 2012; SkarvelisKazakos et al., 2009). Tables 1-4 in the Appendix display material inputs for each of the four turbines. Turbines were assumed to have been transported by diesel truck from their place of manufacture to the nearest large port. They were then transported on freight ships by way of common international shipping lanes to Bangkok. From there, the turbines were assumed to have been transported by diesel truck over a distance of $1000 \mathrm{~km}$. One thousand $\mathrm{km}$ from Bangkok represents the maximum possible distance that the turbines could be transported within Thailand. This was used in order to determine the maximum possible impact from transportation on the life cycle environmental burdens of wind turbines in Thailand.

Multiple studies have looked at Thailand's average annual wind speed both in specific locations, such as Chaing Mai, Ubonratchanthani, Nakhon Si Thammarat, and over the country as a whole (Chainchana and Chaitep, 2010; Unchai et al., 2012; Waewsak et al., 2011; Major et al., 2008). Elevation is important to wind speed. One equation that represents this variation is the power exponential function:

$$
\frac{V_{z}}{V_{z_{r}}}=\left(\frac{z}{z_{r}}\right)^{\lambda}
$$

Where $V_{z}$ represents the actual wind speed recorded at height $z$ and $V_{z r}$ represents the wind speed at theoretical height $z_{r}$. The value $\lambda$ is the power law exponent, which can be calculated:

$$
\lambda=\frac{0.37-0.088 \ln \left(V_{r e f}\right)}{1-0.088 \ln \left(\frac{z_{r e f}}{10}\right)}
$$

Here, $v_{\text {ref }}$ is the reference wind velocity in meters per second and $z_{\text {ref }}$ is the reference height in meters above the ground. One study noted how wind speed 10 meters above the ground was predicted to be about 30\% greater than at 2.5 meters, and about $70 \%$ stronger at 40 meters than at 2.5 meters (Chaichana and Chaitep, 2010).

To analyze the probability of different wind speeds occurring around Thailand, we used the Weibull probability density function. This function can be described as: 


$$
p(V)=\left(\frac{\alpha}{\beta}\right)\left(\frac{V}{\beta}\right)^{\alpha-1} \exp \left[\left(\frac{V}{\beta}\right)^{\alpha}\right]
$$

This function can be used to project the frequency of wind velocities based on two parameters: the shape parameter $(\alpha)$ and the scale parameter $(\beta)$. The two values should be calculated using the mean and standard deviation of wind speeds in an area. The shape parameter can be calculated using the equation:

$$
\alpha=\left(\frac{\sigma_{V}}{\bar{V}}\right)^{-1.086} \quad 1 \leq \alpha \leq 10
$$

The scale parameter can be calculated using the equation:

$$
\beta=\frac{\bar{V}}{\Gamma\left(1+\frac{1}{\alpha}\right)}
$$

Where $\Gamma(x)$ is a gamma function:

$$
\Gamma(x)=\int_{0}^{\alpha} e^{-t} t^{x-1} d t
$$

However, to describe the wind regime in Thailand we decided to use a Wind Atlas of Thailand produced by DEDE which has specific Wind Classes covering the whole country. Using these values made it difficult to calculate a meaningful standard deviation and, to some degree, a meaningful mean. As a result, we assumed that $\alpha$ was equal to 2 . When $\alpha$ is equal to 2 , a Rayleigh distribution is formed. A Rayleigh distribution is a common probability distribution used for estimating wind resources (Jamil et al., 1995).

Using a shape parameter of $2, \beta$ can easily be calculated. A specific $\beta$ value was found for each Wind Class which was then used to calculate the probability density for each Turbine and for each class. With both $\alpha$ and $\beta$ values known, the probability density could be calculated. Below is a sample table from the spreadsheet that was used when doing calculations for the Air X 400 turbine. The rest of the tables associated with these calculations can be found in the Appendix. 


\begin{tabular}{|c|c|c|c|c|c|c|c|c|c|c|c|c|c|c|c|c|c|c|c|}
\hline \multicolumn{20}{|c|}{ Air X 400 Weibull Probability Density Function values by Wind Power Class } \\
\hline \multicolumn{2}{|c|}{ Power Class 11} & \multicolumn{2}{|c|}{ Power Class 12} & \multicolumn{2}{|c|}{ P ower Class 13} & \multicolumn{2}{|c|}{ P ower Class 14} & \multicolumn{2}{|c|}{ Power Class 2} & \multicolumn{2}{|c|}{ Power Class 3} & \multicolumn{2}{|c|}{ Powerclass 4} & \multicolumn{2}{|c|}{ Powerclass 5} & \multicolumn{2}{|c|}{ Power Class 6} & \multicolumn{2}{|c|}{$\mathrm{P}$ ower $\mathrm{C}$ lass 7} \\
\hline $\bar{\alpha}$ & $\beta$ & $\alpha$ & $\beta$ & $\alpha$ & $\beta$ & $\alpha$ & $\beta$ & $\alpha$ & $\beta$ & $\alpha$ & $\beta$ & $\alpha$ & $\beta$ & $\alpha$ & $\beta$ & $\alpha$ & $\beta$ & $\alpha$ & $\beta$ \\
\hline 2 & 141047396 & 2 & 44155646 & 2 & 4.287840835 & 2 & 4.739192502 & 2 & 359801044 & 2 & 6.036828544 & 2 & 6.54459917 & & 6.99595084 & 21 & 7.56014042 & 2 & 9.252709171 \\
\hline & & & & & & & & & & & & & & & & & & & \\
\hline $\mathrm{m} / \mathrm{s}$ & \begin{tabular}{|l|} 
P ro bability \\
D is tribution \\
Function
\end{tabular} & $\mathrm{m} / \mathrm{s}$ & $\begin{array}{l}\text { P robability } \\
\text { Dis tribution } \\
\text { F unction }\end{array}$ & $\mathrm{m} / \mathrm{s}$ & $\begin{array}{l}\text { Probability } \\
\text { Dis tribution } \\
\text { F unction }\end{array}$ & $\mathrm{m} / \mathrm{s}$ & $\begin{array}{l}\text { P robability } \\
\text { D is tribution } \\
\text { F unction }\end{array}$ & $\mathrm{m} / \mathrm{s}$ & \begin{tabular}{|l|} 
Probability \\
Dis tribution \\
F unction
\end{tabular} & $\mathrm{m} / \mathrm{s}$ & \begin{tabular}{|l|} 
P robability \\
D is tribution \\
F unction
\end{tabular} & $\mathrm{m} / \mathrm{s}$ & \begin{tabular}{|l|} 
P robability \\
Dis tribution \\
F unction
\end{tabular} & $\mathrm{m} / \mathrm{s}$ & $\begin{array}{l}\text { P robability } \\
\text { Dis tribution } \\
\text { F unction }\end{array}$ & $\mathrm{m} / \mathrm{s}$ & \begin{tabular}{|l|} 
P robability \\
D is tribution \\
Function
\end{tabular} & $\mathrm{m} / \mathrm{s}$ & \begin{tabular}{|l|} 
P robability \\
Dis tribution \\
F unction
\end{tabular} \\
\hline 0 & 0 & 0 & 0 & 0 & 0 & 0 & 0 & of & o & 0 & 0 & 0 & 0 & 0 & 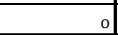 & o & & o & \\
\hline & 0.60813449 & & 0.155186262 & & 0.103022292 & & 0.085169657 & & 0.06723802 & & 0.053394352 & & 0.045616751 & & 0.04003714 & & 0.03438522 & & 0.023089758 \\
\hline 2 & 0.26923343 & 2 & 0.240925343 & 2 & 0.175023668 & 2 & 0.149040979 & 2 & 0.121141146 & 2 & 0.098349995 & 2 & 0.085062027 & 2 & 0.0753135 & 2 & 0.0652539 & 2 & 0.044589338 \\
\hline 3 & 0.03271291 & 3 & 0.236940396 & 3 & 0.200023338 & 3 & 0.178943099 & 3 & 0.152684243 & 3 & 0.128611749 & 3 & 0.113534877 & 3 & 0.10199926 & 3 & 0.08968205 & 3 & 0.063089685 \\
\hline 4 & 0.00129287 & 4 & 0.174948151 & 4 & 0.18225065 & 4 & 0.174702409 & 4 & 0.159554388 & 4 & 0.141514337 & 4 & 0.128555677 & 4 & 0.11787504 & 4 & 0.10579257 & 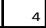 & 0.07751533 \\
\hline 5 & $17529 \mathrm{E}-05$ & 5 & 0.102286196 & 5 & 0.139632281 & 5 & 0.146278774 & 5 & 0.14580052 & 5 & 0.138183927 & 5 & 0.13024031 & 5 & 0.12259454 & 5 & 0.11297418 & 5 & 0.087225314 \\
\hline 6 & $8.3492 \mathrm{E}-08$ & 6 & 0.048491105 & 6 & 0.092115107 & 6 & 0.107562816 & 6 & 0.11930129 & 6 & 0.122617334 & 6 & 0.120890379 & 6 & 0.11750187 & 6 & 0.11183496 & 6 & 0.092049864 \\
\hline 7 & $14148 \mathrm{E}-10$ & 7 & 0.018877254 & 7 & 0.052990557 & 7 & 0.070345409 & 7 & 0.088524048 & 7 & 0.100133125 & 7 & 0.10411769 & 7 & 0.10510834 & 1 & 0.10393088 & & 0.092262184 \\
\hline 8 & $8.5936 \mathrm{E}-14$ & 8 & 0.006080326 & 8 & 0.026783561 & 8 & 0.041226998 & 8 & 0.060018766 & 8 & 0.075825424 & 8 & 0.083834618 & 8 & 0.0884154 & 8 & 0.09136081 & 8 & 0.088496052 \\
\hline 9 & $18803 \mathrm{E}-17$ & 9 & 0.001628327 & 9 & 0.011952418 & 9 & 0.021757823 & 9 & 0.037362673 & 9 & 0.053503047 & 9 & 0.063416716 & 9 & 0.0702801 & 9 & 0.07633768 & 9 & 0.081627983 \\
\hline 10 & $14869 \mathrm{E}-21$ & 10 & 0.000363771 & 10 & 0.004725037 & 10 & 0.010374838 & 10 & 0.021426849 & 10 & 0.035294998 & 10 & 0.04521786 & 10 & 0.05296573 & 10 & 0.06083115 & 10 & 0.072646323 \\
\hline 11 & $4.2596 \mathrm{E}-26$ & 11 & $6.7954 \mathrm{E}-05$ & 11 & 0.00165862 & 11 & 0.004480326 & 11 & 0.01134693 & 11 & 0.021819713 & 11 & 0.030462979 & 11 & 0.03793551 & 11 & 0.04633951 & 11 & 0.062528474 \\
\hline 12 & $4.4284 \mathrm{E}-31$ & 12 & $106332 \mathrm{E}-05$ & 12 & 0.000517895 & 12 & 0.001755339 & 12 & 0.005558516 & 12 & 0.012663297 & 12 & 0.019424575 & 12 & 0.02586699 & 12 & 0.0338046 & 12 & 0.052142557 \\
\hline 13 & $1673 E-36$ & 13 & $139557 \mathrm{E}-06$ & 13 & 0.000144035 & 13 & 0.00062476 & 13 & 0.002522187 & 13 & 0.006908505 & 13 & 0.01173884 & 13 & 0.01681406 & 13 & 0.02364704 & 13 & 0.042182741 \\
\hline 14 & $2.2992 \mathrm{E}-42$ & 14 & 153791E-07 & 14 & $3.57167 \mathrm{E}-05$ & 14 & 0.000202216 & 14 & 0.001061165 & 14 & 0.003546582 & 14 & 0.006730422 & 14 & 0.01042978 & 14 & 0.01587828 & 14 & 0.033140135 \\
\hline 15 & $11504 E-48$ & 15 & $142414 \mathrm{E}-08$ & 15 & 7.90337E-06 & 15 & $5.95693 \mathrm{E}-05$ & 15 & 0.000414316 & 15 & 0.00171467 & 15 & 0.003664029 & 15 & 0.00617887 & 15 & 0.01024264 & 15 & 0.025305022 \\
\hline 16 & $2.0968 \mathrm{E}-55$ & 16 & $110894 \mathrm{E}-09$ & 16 & $156162 \mathrm{E}-06$ & 16 & $159817 \mathrm{E}-05$ & 16 & 0.000150214 & 16 & 0.000781236 & 16 & 0.00189523 & 16 & 0.00349834 & 16 & 0.00635168 & 16 & 0.018792264 \\
\hline 17 & 13931F-62 & 17 & $7.26486 \mathrm{E}-11$ & 17 & $2.75674 \mathrm{E}-07$ & 17 & $3.90707 \mathrm{E}-06$ & 17 & $5.06004 \mathrm{E}-05$ & 17 & 0.000335622 & 17 & 0.000931936 & 17 & 0.00189395 & 17 & 0.00378852 & 17 & 0.013580199 \\
\hline 18 & $3.3752 E-70$ & 18 & $4.00598 \mathrm{E}-12$ & 18 & $4.34978 \mathrm{E}-08$ & 18 & $8.70764 \mathrm{E}-07$ & 18 & $158437 \mathrm{E}-05$ & 18 & 0.000136013 & 18 & 0.000435839 & 18 & 0.00098089 & 18 & 0.00217444 & 18 & 0.009553934 \\
\hline 19 & $2.9832 \mathrm{E}-78$ & 19 & $186 \mathrm{E}-13$ & 19 & $6.13697 \mathrm{E}-09$ & 19 & $176984 \mathrm{E}-07$ & 19 & $4.61297 \mathrm{E}-06$ & 19 & $5.20154 \mathrm{E}-05$ & 19 & 0.00019393 & 19 & 0.00048617 & 19 & 0.0012014 & 19 & 0.006545913 \\
\hline 20 & $9.6215 \mathrm{E}-87$ & 20 & 7.2741 - 15 & 20 & $7.74449 \mathrm{E}-10$ & 20 & $3.28164 \mathrm{E}-08$ & 20 & $12493 E-06$ & 20 & $187778 \mathrm{E}-05$ & 20 & $8.21256 \mathrm{E}-05$ & 20 & 0.00023067 & 20 & 0.00063918 & 20 & 0.004369261 \\
\hline 21 & 11327E-95 & 21 & $2.39676 \mathrm{E}-16$ & 21 & $8.74383 \mathrm{E}-11$ & 21 & $5.5525 \mathrm{E}-09$ & 21 & $3.14794 \mathrm{E}-07$ & 21 & $6.40086 \mathrm{E}-06$ & 21 & $3.3109 \mathrm{E}-05$ & 21 & 0.0001048 & 21 & 0.00032755 & 2 & 0.002841928 \\
\hline
\end{tabular}

Table 1._Air X 400 Weibull Probability Density Calculations

The diesel generator was assumed to be $60 \%$ steel, $35 \%$ aluminum, and $5 \%$ copper by mass (Fleck and Huot, 2009). Based on an assumed lifetime of 10 years, one generator was required to satisfy the functional unit. The battery used in the wind system was also used for the diesel system.

Fuel consumption to satisfy the functional unit was calculated based on the average fuel consumption of various similarly sized generators (See Appenidix). Emissions and embodied energy from the production and combustion of diesel are shown in Table 2 (Fleck and Huot, 2009). Transport of diesel fuel was omitted from the study because it is assumed to be negligible compared to production and combustion.

\begin{tabular}{|c|c|c|}
\hline Process & GWP100 (kg CO2-eq./L) & EE (MJ/L) \\
\hline Production & 0.29 & 3.636 \\
\hline Combustion & 2.86 & 38.592 \\
\hline TOTAL & $\mathbf{3 . 1 5}$ & $\mathbf{4 2 . 2 2 8}$ \\
\hline
\end{tabular}

Table 2. GWP100 and EE from the production and combustion of diesel fuel

The functional unit requires that the energy system produces $600 \mathrm{kWh}$ of usable electricity per year. Assuming an average home inverter efficiency of $92 \%$ and an overall battery efficiency of $75 \%$, the overall energy output requirements to achieve $600 \mathrm{kWh}$ of usable electricity from the wind and diesel systems were calculated. Because diesel generators dispense AC power, inverter efficiency was not 
included in the calculation for the diesel generator's overall energy requirement. The equation below was used to calculate the overall energy requirement.

$$
\text { Overall EnergyOutput }=\frac{\text { Annual Energy Re quirement }}{\text { Battery Efficiency } \times \text { Inverter Efficiency }}
$$

The specific battery model selected is a DC50-12A by Fullriver Battery Company of Guangzhou China. The cheap creation of batteries in this location due to readily available materials and labor coupled with cheap shipping costs from China to Thailand made this battery a viable option for use in the study. The battery weighs 18.5 kilograms and the standard materials based on cut off of $5 \%$ mass are lead (11.1 kilograms), sulfuric acid (1.85 kilograms), and polypropylene (1.85 kilograms). The battery selected for the wind energy systems and diesel generator system is a twelve-volt Deep Cycle battery. The particular Deep Cycle model selected is an absorbed glass mat (AGM) type. This specific battery type was chosen due to its ability to prevent battery acid leaks. The Deep Cycle style of battery has thicker lead plates and can withstand a greater discharge depth than a standard lead-acid battery.

Battery bank sizing has an impact on embodied energy and emissions associated with the wind and diesel generator systems. Consequently, the battery bank size was determined based on the method used in Fleck and Huot (Fleck and Huot, 2009). This method requires that the batteries be able to provide three days' worth of energy before dropping below a state of $50 \%$ charge. The resultant calculation yielded a battery bank size of $14.26 \mathrm{kWh}_{\text {storage }}$ for the wind system and $13.11 \mathrm{kWh}_{\text {storage }}$ for the diesel system. The capacity of the batteries used in this study was determined from the manufacturer specifications (Fullriver.com). The manufacturer's specifications listed capacity in amphours $(\mathrm{AH})$, so this had to be converted to $\mathrm{kWh}$. The resultant storage capacity per battery was

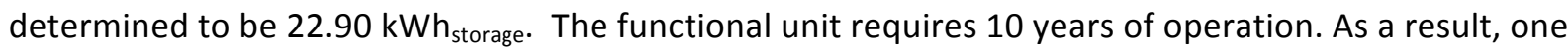
battery bank is used for all calculations based on a battery lifetime of 10 years (Fleck and Huot, 2009).

The inverter used is a 2500 watt $(2.5 \mathrm{~kW})$ standard inverter. This size is appropriate for the given turbines used in the study. Information for this generic inverter was collected from the Ecoinvent database. It weighs approximately 18.5 kilograms and is primarily composed of steel, copper and aluminum (aluminium). The inverter, like the battery, is assumed to have been produced in China in the Guangzhou region. After production it is shipped to a final location in Thailand where it is sold and distributed to appropriate consumers with need for the product. The combination of the inverter and battery with the wind energy system allows for the conversion of direct current to alternating current to be used and stored by the end user. 


\section{Impact Analysis}

With the probability density values calculated, a technique called the Power Curve Method was used to calculate the wind energy potential for wind class for each turbine. This technique of estimating power output potential was derived from the book Wind Power by Paul Gipe (Gipe, 2004). Using the power curve of a specific turbine provided by the manufacturer and a wind distribution, such as the probability density function previously calculated, the energy production potential can be calculated. Gipe notes that the power curves supplied by manufacturers of small wind turbines are often less accurate than the power curves supplied by manufacturers of large wind turbines because requirements are often less strict. This should be considered when analyzing the energy production potentials of the different turbines when using the power curve method. A sample of the outputs from the spreadsheets used to calculate the energy potential of the Air X 400 can be seen in the table below. The rest of the tables associated with these calculations can be found in the Appendix.

\begin{tabular}{|c|c|c|c|c|c|c|c|c|c|}
\hline \multicolumn{10}{|c|}{ Air X 400 Annual Energy Output: Wind Class 1.1} \\
\hline \begin{tabular}{|l|} 
Wind \\
speed \\
$(\mathrm{m} / \mathrm{s})$
\end{tabular} & \begin{tabular}{|l} 
Wind \\
speed \\
$(\mathrm{mph})$
\end{tabular} & \begin{tabular}{|l|} 
Inst. \\
Power \\
\#1 (W)
\end{tabular} & \begin{tabular}{|l} 
Inst. \\
Power \\
$\# 2$ (W)
\end{tabular} & \begin{tabular}{|l|} 
Inst. \\
Power \\
$\# 3$ (W)
\end{tabular} & $\begin{array}{l}\text { F requency } \\
\text { Distribution }\end{array}$ & \begin{tabular}{|l} 
Hours \\
peryear
\end{tabular} & $\begin{array}{l}\text { Energy\#1 } \\
(\mathrm{kWh} / \mathrm{yr})\end{array}$ & \begin{tabular}{|l} 
Energy\#2 \\
$(\mathrm{kWh} / \mathrm{yr})$
\end{tabular} & \begin{tabular}{|l} 
Energy\#3 \\
$(\mathrm{kWh} / \mathrm{yr})$
\end{tabular} \\
\hline 0 & 0 & 0 & 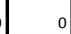 & & & & & 0 & \\
\hline & 2.237 & 0 & 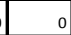 & & 0.6081345 & 5327.3 & & 0 & \\
\hline 2 & 4.474 & 0 & 3 & 0 & 0.2692334 & 2358.5 & 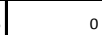 & 0 & \\
\hline 3 & 6.711 & 0 & 8 & 10 & 0.0327129 & 286.57 & 0 & 2.2925200 & \begin{tabular}{|l}
2.8656508 \\
\end{tabular} \\
\hline 4 & 8.948 & 10 & 15 & 20 & 0.0012929 & 11326 & 0.1132558 & 0.1698837 & 0.2265116 \\
\hline 5 & 1118 & 21 & 25 & 25 & $1753 E-05$ & 0.1536 & 0.0032247 & 0.0038389 & \begin{tabular}{|l}
0.0038389 \\
\end{tabular} \\
\hline 6 & 13.42 & 34 & 40 & 35 & $8.349 \mathrm{E}-08$ & 0.0007 & $2.487 \mathrm{E}-05$ & $2.926 \mathrm{E}-05$ & $2.56 \mathrm{E}-05$ \\
\hline 7 & 15.66 & 57 & 50 & 50 & $1415 \mathrm{E}-10$ & $\mathbb{E}-06$ & $7.064 \mathrm{E}-08$ & 6.197e -08 & $6.197 \mathrm{E}-08$ \\
\hline 8 & 17.9 & 92 & 75 & 60 & $8.594 \mathrm{E}-14$ & $8 E-10$ & $6.926 \mathrm{E}-11$ & $5.646 \mathrm{E}-11$ & $4.517 \mathrm{E}-11$ \\
\hline 9 & 20.13 & 143 & 105 & 145 & $188 \mathrm{E}-17$ & $2 E-13$ & $2.355 \mathrm{E}-14$ & $1729 \mathrm{E}-14$ & $2.388 \mathrm{E}-14$ \\
\hline 10 & 22.37 & 178 & 180 & 193 & $1487 \mathrm{E}-21$ & $\mathbb{E}-17$ & $2.318 E-18$ & $2.345 \mathrm{E}-18$ & $2.514 \mathrm{E}-18$ \\
\hline 11 & 24.61 & 264 & 270 & 240 & $4.26 \mathrm{E}-26$ & $4 \mathrm{E}-22$ & $9.85 \mathbb{E}-23$ & $1007 \mathrm{E}-22$ & $8.955 \mathrm{E}-23$ \\
\hline 12 & 26.84 & 322 & 355 & 330 & 4.428E-31 & $4 E-27$ & $1249 E-27$ & $1377 E-27$ & $128 \mathrm{E}-27$ \\
\hline 13 & 29.08 & 391 & 345 & 400 & $1673 E-36$ & $\mathbb{E F}-32$ & $5.73 E-33$ & $5.056 E-33$ & $5.862 E-33$ \\
\hline 14 & 3132 & 276 & 310 & 10 & $2.299 \mathrm{E}-42$ & $2 E-38$ & $5.559 \mathrm{E}-39$ & $6.244 E-39$ & $2.014 E-40$ \\
\hline 15 & 33.55 & 173 & 310 & 10 & $115 \mathrm{E}-48$ & $\mathbb{E}-44$ & $1743 E-45$ & $3.124 E-45$ & $1008 E-46$ \\
\hline 16 & 35.79 & 92 & 305 & 15 & $2.097 \mathrm{E}-55$ & $2 E-51$ & $169 \mathrm{E}-52$ & $5.602 E-52$ & $2.755 E-53$ \\
\hline 17 & 38.03 & 92 & 275 & 20 & $1393 \mathrm{E}-62$ & $\mathbb{E F}-58$ & $1123 E-59$ & $3.356 E-59$ & $2.44 \mathbb{E}-60$ \\
\hline 18 & 40.26 & 92 & 250 & & $3.375 \mathrm{E}-70$ & $3 E-66$ & $2.72 E-67$ & $7.392 \mathrm{E}-67$ & \\
\hline 19 & 42.5 & 92 & 250 & & $2.983 E-78$ & $3 E-74$ & $2.404 E-75$ & $6.533 E-75$ & \\
\hline 20 & 44.74 & 92 & 250 & & $9.622 E-87$ & $8 E-83$ & $7.754 \mathrm{E}-84$ & $2.107 E-83$ & \\
\hline 21 & 46.98 & & 240 & & $1133 \mathrm{E}-95$ & IF-91 & 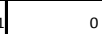 & $2.381 \mathbb{E}-92$ & \\
\hline & & & & & & & & & \\
\hline tal: & & & & & & & 0.1165054 & 2.4662726 & 3.09602 \\
\hline
\end{tabular}

\begin{tabular}{|c|c|c|c|c|c|c|c|c|c|}
\hline \multicolumn{10}{|c|}{ Air X 400 Annual Energy Output: Wind Class 1.2} \\
\hline $\begin{array}{l}\text { ind } \\
\text { eeed } \\
1 / s)\end{array}$ & \begin{tabular}{|l} 
Wind \\
speed \\
spph
\end{tabular} & $\begin{array}{l}\text { Inst. } \\
\text { Power } \\
\# 1(\text { W) }\end{array}$ & $\begin{array}{l}\text { Inst. } \\
\text { Power } \\
\# 2(\mathbf{W})\end{array}$ & \begin{tabular}{|l} 
Inst. \\
Po ower \\
$\# 3$ (W)
\end{tabular} & $\begin{array}{l}\text { Fr requency } \\
\text { Dis tribution }\end{array}$ & $\begin{array}{l}\text { Hours } \\
\text { per year }\end{array} \mid$ & $\begin{array}{l}\text { Energy\#1 } \\
(\mathrm{kWh} / \mathrm{yr})\end{array}$ & $\begin{array}{l}\text { Energy\#2 } \\
(\mathrm{kWh} / \mathrm{yr})\end{array}$ & $\begin{array}{l}\text { Energy\#3 } \\
(\mathrm{kWh} / \mathrm{yr})\end{array}$ \\
\hline 0 & & & & & & & & & \\
\hline & 2.237 & & & & 0.1551863 & 1359.4 & & & \\
\hline 2 & 4.474 & & & & 0.2409253 & 2110.5 & & & \\
\hline 3 & 6.711 & & & 10 & 0.2369404 & 2075.6 & & 16.604783 & 20.755 \\
\hline 4 & 8.948 & $\Perp$ & 15 & 20 & 0.1749482 & 1532.5 & 15.325458 & 22.988187 & 0.650 \\
\hline  & 1118 & 2 & 25 & 25 & 0.1022862 & 896.03 & 18.816569 & 22.400677 & 22.4006 \\
\hline 6 & 13.42 & 3. & 40 & 35 & 0.048491 & 424.78 & 14.44259 & 16.991283 & 14.8673 \\
\hline 7 & 15.66 & 5 & 50 & 50 & 0.0188773 & 165.36 & 9.4257904 & \begin{tabular}{|l}
8.2682372 \\
\end{tabular} & 8.26823 \\
\hline 8 & 17.9 & 9 & 75 & 60 & 0.0060803 & 53.264 & 4.9002562 & \begin{tabular}{|l}
.9947741 \\
\end{tabular} & 3.195 \\
\hline 9 & 20.13 & 14 & 105 & 145 & 0.0016283 & 14.264 & 2.0397727 & 14977352 & 2.06830 \\
\hline 10 & 22.37 & 178 & 180 & 193 & 0.0003638 & 3.1866 & 0.567220 & 0.5735934 & 0.61501 \\
\hline 11 & 24.61 & 26 & 270 & 240 & $6.795 \mathrm{E}-05$ & 0.5953 & 0.157153 & \begin{tabular}{|l|l|l}
0.1607247 \\
\end{tabular} & 0.14286 \\
\hline 12 & 26.84 & 32 & 355 & 330 & $1063 \mathrm{E}-05$ & 0.0931 & \begin{tabular}{|l}
0.0299933 \\
\end{tabular} & \begin{tabular}{|l}
0.0330671 \\
\end{tabular} & 0.03073 \\
\hline 13 & 29.08 & 39 & 345 & 400 & $1396 \mathrm{E}-06$ & 0.0122 & 0.004780 & 0.0042177 & 0.00489 \\
\hline 14 & 3132 & 27 & 310 & 10 & $1538 \mathrm{E}-07$ & 0.0013 & 0.0003718 & 0.0004176 & 1347E- \\
\hline 15 & 33.55 & 17 & 310 & 10 & $1424 \mathrm{E}-08$ & 0.0001 & $2.158 \mathrm{E}-0.5$ & \begin{tabular}{|l|l}
$3.867 \mathrm{E}-05$ \\
\end{tabular} & $1248 \mathrm{E}$. \\
\hline 16 & 35.79 & 9 & 305 & 15 & $1109 \mathrm{E}-09$ & $\mathbb{E}-05$ & $8.937 \mathrm{E}-07$ & $2.963 \mathrm{E}-06$ & $1457 \mathrm{E}$ \\
\hline 17 & 38.03 & 9 & 275 & 20 & $7.265 \mathrm{E}-1$ & $6 E-07$ & $5.855 \mathrm{E}-08$ & $175 \mathrm{E}-07$ & $1273 \mathrm{E}-\mathrm{C}$ \\
\hline 18 & 40.26 & 9 & 250 & & $4.006 \mathrm{E}-12$ & $4 \mathrm{E}-08$ & $3.228 \mathrm{E}-09$ & \begin{tabular}{|l|l}
$8.773 \mathrm{E}-09$ \\
\end{tabular} & \\
\hline 19 & 42.5 & 9 & 250 & & $186 \mathrm{E}-13$ & $2 E-09$ & $1499 \mathrm{E}-10$ & $4.073 E-10$ & \\
\hline 20 & 44.74 & 9 & 250 & & $7.274 \mathrm{E}-15$ & $6 E-11$ & $5.862 \mathrm{E}-12$ & $1593 \mathrm{E}-11$ & \\
\hline 21 & 46.98 & & 240 & & $2.397 \mathrm{E}-16$ & $2 E-12$ & & $5.039 \mathrm{E}-13$ & \\
\hline & & & & & & & & & \\
\hline al: & & & & & & & \begin{tabular}{|l}
65.709977 \\
\end{tabular} & \begin{tabular}{|l}
93.517739 \\
\end{tabular} & 103.000 \\
\hline
\end{tabular}

Table 3. Air X 400 Annual Energy Output

Because of the noted unreliability of manufacturer-published power curves, an alternative method of energy potential calculation was also used. This method was also taken from Gipe, and calculates the energy potential as a function of the average power in a cross section of the wind, the area swept by the turbine rotors, and the overall efficiency of the turbine at converting energy in the wind into electricity. Apart from the actual velocity of the wind, and thus the power available in it, the swept area of a turbine is the most important factor for determining the energy potential from that 
turbine (Gipe, 2004). The power per unit area of the wind, or power density, is obtained from the following equation

$$
\text { Power per unit area }=\frac{1}{2} \rho V^{3}
$$

Where $\rho$ is the density of the air and $V$ is the average velocity of the wind. By multiplying by the number of hours in a year, it is possible to determine the annual energy output (AEO) of the turbine. AEO is thus calculated by the following equation

$$
A E O=\left(\frac{W}{m^{2}}\right) \times(A) \times(\% \text { efficiency }) \times\left(\frac{8760 \mathrm{hr}}{\text { year }}\right) \times\left(\frac{1 \mathrm{~kW}}{1000 \mathrm{~W}}\right)
$$

where $A$ is the circular area swept by the turbine rotors and the \% efficiency is the average percent of the energy in the wind that the turbine is assumed to be able to capture over the period of interest. According to Gipe, typical efficiencies for small wind turbines are below $25 \%$, with larger turbines usually achieving higher efficiencies than smaller turbines in the same conditions (Gipe, 2004). Because of lack of available data regarding the actual functional efficiencies of the turbines included in this study, efficiencies for all of the turbines were assumed to be $20 \%$. This was meant to represent a near-bestcase scenario. The following table shows the results of AEO calculations for all four turbines in each of the ten wind classes.

\begin{tabular}{|l|l|l|l|l|l|l|l|l|l|l|l|}
\hline & & \multicolumn{8}{|c|}{ AEO for various Wind Classes (assumed 20\% efficiency) (kWh) } \\
\hline Turbine & swept area $\left.\mathbf{( m}^{\mathbf{2}}\right)$ & 1.1 & 1.2 & 1.3 & 1.4 & 2 & 3 & 4 & 5 & 6 & 7 \\
\hline Jacob's 31-20 & 70.9 & 427 & 4730 & 7890 & 11100 & 15500 & 21400 & 27500 & 33200 & 41800 & 76800 \\
\hline Endurance s-343 & 31.9 & 180 & 2000 & 3350 & 4720 & 6610 & 9170 & 11800 & 14300 & 18000 & 33100 \\
\hline WES5 Tulipo & 19.6 & 48.5 & 688 & 1320 & 1770 & 2540 & 3620 & 4590 & 5580 & 7010 & 12700 \\
\hline Air X & 1.08 & 2.22 & 32.3 & 62.3 & 84.1 & 122 & 174 & 222 & 271 & 341 & 626 \\
\hline
\end{tabular}

Table 4. AEO from swept area

It should be noted that in some cases, the AEO values presented in Table 4 for the lower wind classes are not actually possible because the average wind speed is below the cut-in wind speed of the turbine. While the rotors may turn slowly at these wind speeds, there would not be any power produced by the generator. This will be discussed more thoroughly later. 


\section{Economic Assessment}

Economic assessment, as well as environmental assessment, is vital in determining the feasibility of an energy technology. Levelized cost of electricity (LCOE) was used as a comparison method between the wind turbine system, diesel generator system, and Thai electricity grid introduced above. The LCOE takes into account the life cycle costs of an energy technology project, ranging from initial cost to residual value, and compares it to the lifetime energy production of that project. The LCOE is the "break-even" value that an electricity producer must charge to validate investment in a project (Stanford). Similarly, for this study it is the value that the independent investor "pays" to produce electricity from a project. The end result of an LCOE calculation is a price of electricity per kWh. A simple representation of LCOE is seen below (Stanford).

$$
L C O E=\frac{\text { Total Life Cycle Cost }}{\text { Total Lifetime Energy } \operatorname{Pr} \text { oduction }}
$$

The full expression for LCOE is shown below (Stanford).

$$
\frac{I-\sum_{t=1}^{T} \frac{d_{t}}{(1-r)^{t}} \times \alpha+\sum_{t=1}^{T} \frac{a_{t}}{(1-r)^{t}} \times(1-\alpha)+\frac{R}{(1-r)^{T}}}{E \times \sum_{t=1}^{T} \frac{x_{t}}{(1-r)^{t}}}
$$

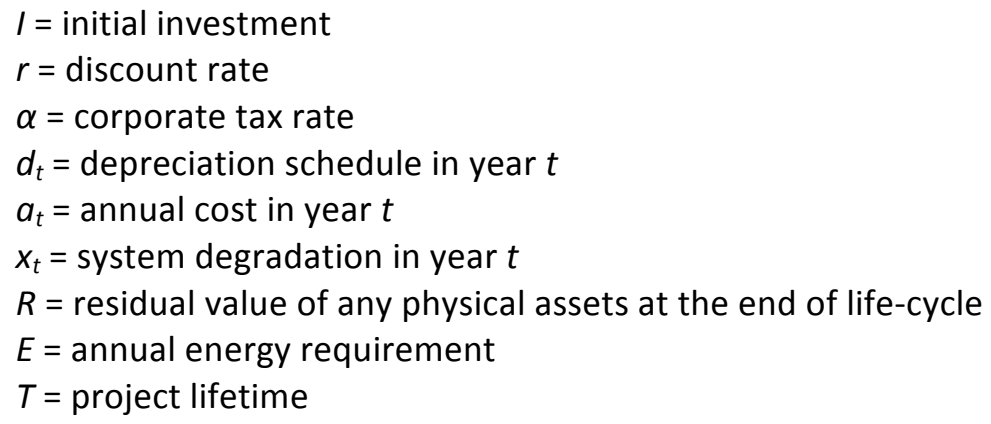

To simplify the LCOE calculation, to be similar to that calculated by the National Renewable Energy Laboratory (NREL), corporate tax rate, depreciation, residual value, and system degradation were excluded (NREL). The following equation is the modified equation used for calculating LCOE.

Additionally, Table 5 shows the values used to calculate the LCOE for wind and diesel systems, respectively. Maintenance costs for each system were omitted, because they were assumed to be negligible. 


$$
L C O E=\frac{I+\sum_{t=1}^{T} \frac{a_{t}}{(1-r)^{t}}}{E \times \sum_{t=1}^{T} \frac{1}{(1-r)^{t}}}
$$

\begin{tabular}{|c|c|c|}
\hline System & Wind & Diesel \\
\hline$I$ & See Appendix 1 & See Appendix 2 \\
\hline$r$ & $2 \%$ & Price of diesel - see Appendix 2 \\
\hline$a_{t}$ & 0 & $800 \mathrm{kWh}$ \\
\hline$E$ & $869.57 \mathrm{kWh}$ & 10 years \\
\hline$T$ & 10 years & \\
\hline
\end{tabular}

Table 5. Values used to calculate LCOE for the wind and diesel systems.

A discount rate of $2 \%$ was selected because it is the risk-free rate of return. Therefore, economic results for the energy system are considered safe investments. The risk-free rate is taken to be the rate of return on government bonds for the lifetime period (Money Terms). The AEO for each system was determined as above.

\section{Results \& Discussion}

\section{Impact Assessment}

In most cases, the turbines chosen for this study more than satisfy the requirements of our functional unit. Because of this and the fact that wind turbines can generally be expected to last significantly longer than our functional unit, only a fraction of each turbine is required. The calculated embodied energies per functional unit for all of the turbines in all of the wind classes that are viable for turbine utilization were significantly lower than the embodied energy of the diesel generator per functional unit.

Results from analysis of the Air X and WES5 Tulipo showed lower values for GWP and embodied energy from the power curve method than from the swept area method. If the published power curves are taken to be accurate in a real-world setting, these results suggest that these turbines are capable of capturing more than $20 \%$ of the power in the wind. This is surprising because the values shown below in Table 6 for GWP include the impact of the inverter and battery (in)efficiencies. Similar tables for embodied energy and energy payback period appear in the Appendix. Cells that are highlighted in red denote values which are likely inaccurate because of the low average wind speed relative to the cut-in wind speed of the turbine. This is not an issue when assessing power output from the power curve method because it implicitly includes the probability distribution of wind speeds with a given average. 
Gipe suggests that smaller wind turbines are not actually capable of returning this level of efficiency consistently (Gipe, 2004).

\begin{tabular}{|c|c|c|c|c|c|c|c|c|}
\hline $\begin{array}{l}\text { Wind Turbine } \\
\text { (Power Rating) }\end{array}$ & \multicolumn{2}{|c|}{ Air X $400(400 W)$} & \multicolumn{2}{|c|}{ Wes5 Tulipo (2.5kW) } & \multicolumn{2}{|c|}{$\begin{array}{c}\text { Endurance S-343 } \\
(5 \mathrm{~kW})\end{array}$} & \multicolumn{2}{|c|}{ Jacobs $31-20(20 \mathrm{~kW})$} \\
\hline $\begin{array}{c}\text { AOE Calculation } \\
\text { Method }\end{array}$ & $\begin{array}{l}\text { Power } \\
\text { Curve }\end{array}$ & $\begin{array}{c}20 \% \\
\text { Efficiency }\end{array}$ & $\begin{array}{l}\text { Power } \\
\text { Curve }\end{array}$ & $\begin{array}{c}20 \% \\
\text { Efficiency }\end{array}$ & $\begin{array}{l}\text { Power } \\
\text { Curve }\end{array}$ & $\begin{array}{c}20 \% \\
\text { Efficiency }\end{array}$ & $\begin{array}{l}\text { Power } \\
\text { Curve }\end{array}$ & $\begin{array}{c}20 \% \\
\text { Efficiency }\end{array}$ \\
\hline Wind Class & \multicolumn{8}{|c|}{ GWP100 (kg CO2-eq.) } \\
\hline 1.1 & $4.72 E+03$ & $4.04 E+03$ & $2.38 \mathrm{E}+05$ & $9.81 \mathrm{E}+03$ & $2.72 E+05$ & $1.82 E+04$ & $7.33 E+04$ & $2.86 \mathrm{E}+04$ \\
\hline 1.2 & $2.04 \mathrm{E}+02$ & $3.74 \mathrm{E}+02$ & $5.66 \mathrm{E}+02$ & $7.88 \mathrm{E}+02$ & $9.37 E+02$ & $1.73 E+03$ & $1.20 E+03$ & $2.67 E+03$ \\
\hline 1.3 & $1.58 \mathrm{E}+02$ & $2.44 \mathrm{E}+02$ & $2.31 E+02$ & $4.60 \mathrm{E}+02$ & $5.57 E+02$ & $1.07 E+03$ & $7.32 E+02$ & $1.64 \mathrm{E}+03$ \\
\hline 1.4 & $1.44 \mathrm{E}+02$ & $2.07 E+02$ & $1.96 \mathrm{E}+02$ & $3.69 E+02$ & 4.27E+02 & $7.93 \mathrm{E}+02$ & $5.58 \mathrm{E}+02$ & $1.20 \mathrm{E}+03$ \\
\hline 2 & $1.32 \mathrm{E}+02$ & $1.75 \mathrm{E}+02$ & $1.74 \mathrm{E}+02$ & $2.89 E+02$ & $3.48 \mathrm{E}+02$ & $5.96 \mathrm{E}+02$ & $4.53 E+02$ & $8.87 E+02$ \\
\hline 3 & $1.24 \mathrm{E}+02$ & $1.54 \mathrm{E}+02$ & $1.61 \mathrm{E}+02$ & $2.34 \mathrm{E}+02$ & $3.00 E+02$ & $4.58 \mathrm{E}+02$ & $3.89 E+02$ & $6.71 E+02$ \\
\hline 4 & $1.20 \mathrm{E}+02$ & $1.43 \mathrm{E}+02$ & $1.53 E+02$ & $2.06 \mathrm{E}+02$ & $2.75 E+02$ & $3.79 E+02$ & $3.57 E+02$ & $5.45 E+02$ \\
\hline 5 & $1.18 \mathrm{E}+02$ & $1.36 \mathrm{E}+02$ & $1.49 \mathrm{E}+02$ & $1.88 \mathrm{E}+02$ & $2.61 E+02$ & $3.31 \mathrm{E}+02$ & $3.40 E+02$ & $4.70 E+02$ \\
\hline 6 & $1.16 \mathrm{E}+02$ & $1.29 \mathrm{E}+02$ & $1.45 \mathrm{E}+02$ & $1.71 \mathrm{E}+02$ & $2.48 \mathrm{E}+02$ & $2.84 \mathrm{E}+02$ & $3.26 \mathrm{E}+02$ & $3.94 \mathrm{E}+02$ \\
\hline 7 & $1.13 E+02$ & $1.18 \mathrm{E}+02$ & $1.39 E+02$ & $1.41 E+02$ & $2.32 \mathrm{E}+02$ & $2.02 \mathrm{E}+02$ & $3.16 \mathrm{E}+02$ & $2.62 \mathrm{E}+02$ \\
\hline
\end{tabular}

Table 6. GWP per functional unit using both power curve and swept area methods

The following two tables display the GWP per functional unit resulting from the use of the diesel generator and the Thai grid, respectively.

\begin{tabular}{|c|c|}
\hline \multicolumn{2}{|c|}{ Diesel Generator } \\
\hline $\begin{array}{c}\mathbf{5 0 \%} \\
\text { Capacity }\end{array}$ & $\begin{array}{l}\mathbf{1 0 0 \%} \\
\text { Capacity }\end{array}$ \\
\hline \multicolumn{2}{|c|}{ GWP100 (kg CO2-eq.) } \\
\hline $1.57 \mathrm{E}+04$ & $9.54 \mathrm{E}+03$ \\
\hline
\end{tabular}

Table 7. GWP per functional unit for diesel generator.

\begin{tabular}{|c|c|}
\hline \multicolumn{2}{|c|}{ Thai Grid } \\
\hline Inside MEA & Outside MEA \\
\hline \multicolumn{2}{|c|}{ GWP100 (kg CO2-eq.) } \\
\hline \multicolumn{2}{|c|}{$6.36 \mathrm{E}+03$} \\
\hline
\end{tabular}

Table 8. GWP per functional unit for Thai grid mix

As can be seen in Table 8, in most cases the GWP per functional unit is again significantly lower for small wind turbines than for the use of the Thai grid, which has a significantly lower GWP than the use of a diesel generator as well. This suggests that wind turbines would be a good option for alternative energy development in Thailand from and environmental perspective. One trend that holds across both impact categories is that the larger turbines have much smaller differences with the generator and Thai grid than do the smaller turbines. This can be seen when comparing Table 6 to Table 8 , as the Jacob's turbine has a GWP that is on the same order of magnitude as that of the Thai grid in the more common wind classes (1.1-1.3). This trend is likely an artifice of our chosen functional unit, as these turbines have the potential to produce many times the energy required to satisfy our functional 
unit over the course of their lifetime. Table 9 contains information regarding calculated embodied energies of the four turbines, and Table 10 contains calculated EPPs for each of the turbines.

\begin{tabular}{|c|c|c|c|c|c|c|c|c|}
\hline \multirow{2}{*}{$\begin{array}{c}\begin{array}{c}\text { Wind Turbine } \\
\text { (Power Rating) }\end{array} \\
\text { AOE Calculation } \\
\text { Method }\end{array}$} & \multicolumn{2}{|c|}{ Air X $400(400 W)$} & \multicolumn{2}{|c|}{ Wes5 Tulipo (2.5kW) } & \multicolumn{2}{|c|}{$\begin{array}{c}\text { Endurance S-343 } \\
(5 \mathrm{~kW})\end{array}$} & \multicolumn{2}{|c|}{ Jacobs $31-20(20 \mathrm{~kW})$} \\
\hline & $\begin{array}{l}\text { Power } \\
\text { Curve }\end{array}$ & $\begin{array}{c}20 \% \\
\text { Efficiency }\end{array}$ & $\begin{array}{l}\text { Power } \\
\text { Curve }\end{array}$ & $\begin{array}{c}20 \% \\
\text { Efficiency }\end{array}$ & $\begin{array}{l}\text { Power } \\
\text { Curve }\end{array}$ & $\begin{array}{c}20 \% \\
\text { Efficiency }\end{array}$ & $\begin{array}{l}\text { Power } \\
\text { Curve }\end{array}$ & $\begin{array}{c}20 \% \\
\text { Efficiency }\end{array}$ \\
\hline Wind Class & \multicolumn{8}{|c|}{ EE (MJ) } \\
\hline 1.1 & $5.59 E+04$ & $4.77 \mathrm{E}+04$ & $3.48 E+06$ & $1.43 E+05$ & $5.99 E+06$ & $3.99 E+05$ & $1.53 \mathrm{E}+06$ & $5.95 \mathrm{E}+05$ \\
\hline 1.2 & $1.81 \mathrm{E}+03$ & $3.85 E+03$ & $7.38 \mathrm{E}+03$ & $1.06 \mathrm{E}+04$ & $1.89 \mathrm{E}+04$ & $3.64 E+04$ & $2.35 E+04$ & $5.43 E+04$ \\
\hline 1.3 & $1.26 \mathrm{E}+03$ & $2.29 E+03$ & $2.48 E+03$ & $5.83 E+03$ & $1.06 \mathrm{E}+04$ & $2.20 \mathrm{E}+04$ & $1.37 \mathrm{E}+04$ & $3.28 \mathrm{E}+04$ \\
\hline 1.4 & $1.10 \mathrm{E}+03$ & $1.86 \mathrm{E}+03$ & $1.97 \mathrm{E}+03$ & $4.50 \mathrm{E}+03$ & $7.68 \mathrm{E}+03$ & $1.58 \mathrm{E}+04$ & $1.01 \mathrm{E}+04$ & $2.35 E+04$ \\
\hline 2 & $9.55 \mathrm{E}+02$ & $1.47 \mathrm{E}+03$ & $1.65 \mathrm{E}+03$ & $3.33 \mathrm{E}+03$ & $5.96 \mathrm{E}+03$ & $1.14 \mathrm{E}+04$ & $7.91 \mathrm{E}+03$ & $1.70 \mathrm{E}+04$ \\
\hline 3 & $8.60 E+02$ & $1.22 \mathrm{E}+03$ & $1.45 E+03$ & $2.52 \mathrm{E}+03$ & $4.89 E+03$ & $8.38 \mathrm{E}+03$ & $6.58 \mathrm{E}+03$ & $1.25 \mathrm{E}+04$ \\
\hline 4 & $8.15 E+02$ & $1.09 E+03$ & $1.34 \mathrm{E}+03$ & $2.11 \mathrm{E}+03$ & $4.33 E+03$ & $6.64 \mathrm{E}+03$ & $5.91 E+03$ & $9.84 E+03$ \\
\hline 5 & $7.87 E+02$ & $1.00 \mathrm{E}+03$ & $1.28 \mathrm{E}+03$ & $1.85 \mathrm{E}+03$ & $4.02 E+03$ & $5.58 \mathrm{E}+03$ & $5.56 \mathrm{E}+03$ & $8.26 \mathrm{E}+03$ \\
\hline 6 & $7.62 E+02$ & $9.22 \mathrm{E}+02$ & $1.22 \mathrm{E}+03$ & $1.60 \mathrm{E}+03$ & $3.74 \mathrm{E}+03$ & $4.54 \mathrm{E}+03$ & $5.27 \mathrm{E}+03$ & $6.69 \mathrm{E}+03$ \\
\hline 7 & $7.24 \mathrm{E}+02$ & $7.82 \mathrm{E}+02$ & $1.14 \mathrm{E}+03$ & $1.16 \mathrm{E}+03$ & $3.39 E+03$ & $2.73 E+03$ & $5.06 \mathrm{E}+03$ & $3.92 E+03$ \\
\hline
\end{tabular}

Table 9. Calculated embodied energies including credits from disposal in various wind classes

\begin{tabular}{|c|c|c|c|c|c|c|c|c|}
\hline \multirow{2}{*}{$\begin{array}{c}\text { Wind Turbine } \\
\text { (Power Rating) }\end{array}$} & \multicolumn{2}{|c|}{ Air X $400(400 W)$} & \multicolumn{2}{|c|}{$\begin{array}{c}\text { Wes5 Tulipo } \\
(2.5 \mathrm{~kW})\end{array}$} & \multicolumn{2}{|c|}{$\begin{array}{c}\text { Endurance } S-343 \\
(5 \mathrm{~kW})\end{array}$} & \multicolumn{2}{|c|}{$\begin{array}{c}\text { Jacobs 31-20 } \\
(20 \mathrm{~kW})\end{array}$} \\
\hline & $\begin{array}{l}\text { Power } \\
\text { Curve }\end{array}$ & $\begin{array}{c}20 \% \\
\text { Efficienc } \\
y\end{array}$ & $\begin{array}{l}\text { Power } \\
\text { Curve }\end{array}$ & $\begin{array}{c}20 \% \\
\text { Efficienc } \\
y\end{array}$ & $\begin{array}{l}\text { Power } \\
\text { Curve }\end{array}$ & $\begin{array}{c}20 \% \\
\text { Efficienc } \\
y\end{array}$ & $\begin{array}{l}\text { Power } \\
\text { Curve }\end{array}$ & $\begin{array}{c}20 \% \\
\text { Efficienc } \\
y\end{array}$ \\
\hline Wind Class & \multicolumn{8}{|c|}{$\operatorname{EPP}(y r)$} \\
\hline 1.1 & $\begin{array}{c}8197.5 \\
5 \\
\end{array}$ & 5971.38 & $\begin{array}{c}487250 \\
.82 \\
\end{array}$ & 816.52 & $\begin{array}{c}138797 \\
.03\end{array}$ & 615.62 & $\begin{array}{c}2560.7 \\
6 \\
\end{array}$ & 386.98 \\
\hline 1.2 & 5.76 & 33.13 & 2.02 & 4.29 & 1.35 & 5.06 & 0.59 & 3.19 \\
\hline 1.3 & 2.16 & 10.23 & 0.19 & 1.23 & 0.41 & 1.82 & 0.20 & 1.15 \\
\hline 1.4 & 1.41 & 6.14 & 0.11 & 0.71 & 0.21 & 0.93 & 0.11 & 0.59 \\
\hline 2 & 0.86 & 3.35 & 0.07 & 0.36 & 0.12 & 0.48 & 0.06 & 0.30 \\
\hline 3 & 0.56 & 1.94 & 0.05 & 0.19 & 0.08 & 0.25 & 0.04 & 0.16 \\
\hline 4 & 0.43 & 1.36 & 0.04 & 0.13 & 0.06 & 0.16 & 0.03 & 0.10 \\
\hline 5 & 0.36 & 1.03 & 0.03 & 0.09 & 0.05 & 0.11 & 0.03 & 0.07 \\
\hline 6 & 0.30 & 0.75 & 0.03 & 0.06 & 0.05 & 0.07 & 0.03 & 0.04 \\
\hline 7 & 0.21 & 0.35 & 0.02 & 0.03 & 0.04 & 0.02 & 0.02 & 0.01 \\
\hline
\end{tabular}

Table 10. Energy payback period for wind turbines in various wind classes

As mentioned previously, the embodied energies of the wind turbines per functional unit seen in Table 9 are lower than that of the diesel generator system in the majority of possible turbine applications, but as with GWP, the embodied energy is much higher in the most common, lightest wind classes. Table 10 shows that in all but the lowest wind class, all technically feasible turbine applications would pay back the embodied energy of the turbines multiple times over the course of our functional unit. This is yet 
more evidence that wind turbines are a very good alternative to diesel generation from an environmental perspective.

\section{Economic Assessment}

Results from LCOE calculations show that there is a substantial difference in the cost of using a diesel generator as the primary means of electricity production and the cost of relying upon the Thai grid. The LCOE of the turbines analyzed for this study were highly dependent on the wind class in which the turbines were operating. In most wind classes, the wind turbines had a lower LCOE than that of the diesel generator, especially if the generator is running at less than maximum capacity. However, it appears very difficult for the turbines analyzed in this study to compete with the LCOE of the Thai grid. Table 11 shows the LCOE of each of the turbines analyzed in this study for which adequate pricing data was available (such data was not found for the WES5 Tulipo, therefore it is excluded). Table 12 and Table 13 display the LCOE of the diesel generator system and the Thai grid mix, respectively.

\begin{tabular}{|c|c|c|c|c|c|c|}
\hline \multirow{2}{*}{$\begin{array}{c}\text { Wind Turbine (Power } \\
\text { Rating) } \\
\text { AOE Calculation } \\
\text { Method }\end{array}$} & \multicolumn{2}{|c|}{ Air X 400 (400W) } & \multicolumn{2}{|c|}{ Endurance S-343 (5kW) } & \multicolumn{2}{|c|}{ Jacobs $31-20(20 \mathrm{~kW})$} \\
\hline & $\begin{array}{l}\text { Power } \\
\text { Curve }\end{array}$ & $\begin{array}{c}20 \% \\
\text { Efficiency }\end{array}$ & $\begin{array}{l}\text { Power } \\
\text { Curve }\end{array}$ & $\begin{array}{c}20 \% \\
\text { Efficiency }\end{array}$ & $\begin{array}{l}\text { Power } \\
\text { Curve }\end{array}$ & $\begin{array}{c}20 \% \\
\text { Efficiency }\end{array}$ \\
\hline Wind Class & \multicolumn{6}{|c|}{ LCOE (\$/kWh) } \\
\hline 1.1 & 632.93 & 539.92 & 3745.26 & 250.75 & 716.63 & 278.62 \\
\hline 1.2 & 15.27 & 38.59 & 13.08 & 24.02 & 11.43 & 25.83 \\
\hline 1.3 & 8.98 & 20.78 & 7.85 & 14.98 & 6.88 & 15.79 \\
\hline 1.4 & 7.13 & 15.80 & 6.05 & 11.10 & 5.19 & 11.44 \\
\hline 2 & 5.48 & 11.39 & 4.97 & 8.38 & 4.16 & 8.40 \\
\hline 3 & 4.39 & 8.46 & 4.30 & 6.49 & 3.54 & 6.29 \\
\hline 4 & 3.88 & 6.98 & 3.95 & 5.40 & 3.23 & 5.06 \\
\hline 5 & 3.56 & 6.00 & 3.76 & 4.73 & 3.06 & 4.32 \\
\hline 6 & 3.27 & 5.10 & 3.58 & 4.09 & 2.92 & 3.59 \\
\hline 7 & 2.84 & 3.50 & 3.37 & 2.95 & 2.83 & 2.29 \\
\hline
\end{tabular}

Table 11. LCOE of turbines with available pricing data

\begin{tabular}{|c|c|}
\hline \multicolumn{2}{|c|}{ Diesel Generator } \\
\hline $\begin{array}{c}\mathbf{5 0 \%} \\
\text { Capacity }\end{array}$ & $\begin{array}{c}\mathbf{1 0 0 \%} \\
\text { Capacity }\end{array}$ \\
\hline \multicolumn{2}{|c|}{ LCOE (\$/kWh) } \\
\hline 22.02 & 14.75 \\
\hline
\end{tabular}

Table 12. LCOE of diesel generator system 
Table 13. LCOE of Thai grid mix

\begin{tabular}{|c|c|}
\hline \multicolumn{2}{|c|}{ Thai Grid } \\
\hline Inside MEA & Outside MEA \\
\hline \multicolumn{2}{|c|}{ LCOE (\$/kWh) } \\
\hline 3.5 & 3.15 \\
\hline
\end{tabular}

Diesel generators have a fairly low cost of initial investment, but end up being more expensive per unit energy than the wind turbines analyzed in this study because of the price of diesel fuel. Conversely, the higher power-rated turbines have a lower LCOE over the course of our functional unit (provided adequate wind resources), but the initial investment costs are prohibitively high for people living in rural communities in Thailand.

\section{Sensitivity Analysis}

A sensitivity analysis was performed to test the effect of varying wind turbine efficiencies when calculating the AEO using the swept area method. Gipe notes that small wind turbines can be expected to capture about $12 \%$ of the power in the wind in very windy conditions. For this reason, AEO was recalculated for each of the turbines using efficiencies of $18 \%, 16 \%, 14 \%, 12 \%$, and $10 \%$. This variation in turbine efficiency allows us to demonstrate the effect that higher- and lower-than-can-be-expected efficiencies have on turbine viability for each of the ten wind classes (Gipe, 2004). The following table displays the results of AEO calculations for each of the four turbines in all ten wind classes with an assumed $12 \%$ efficiency. Similar tables for the other tested efficiency values appear in the Appendix.

\begin{tabular}{|c|c|c|c|c|c|c|c|c|c|c|c|}
\cline { 3 - 13 } \multicolumn{1}{c|}{} & \multicolumn{8}{c|}{ AEO for various Wind Classes (assumed 12\% efficiency) (kWh) } \\
\hline Turbine & swept area & 1.1 & 1.2 & 1.3 & 1.4 & 2 & 3 & 4 & 5 & 6 & 7 \\
\hline Jacob's 31-20 & $70.9 \mathrm{~m} 2$ & 256 & 2840 & 4730 & 6660 & 9320 & 12900 & 16500 & 19900 & 25100 & 46100 \\
\hline Endurance s-343 & $31.9 \mathrm{~m} 2$ & 108 & 1200 & 2010 & 2850 & 3970 & 5500 & 7080 & 8560 & 10800 & 19900 \\
\hline WES5 Tulipo & $19.6 \mathrm{~m} 2$ & 31.1 & 413 & 791 & 1060 & 1530 & 2170 & 2750 & 3350 & 4200 & 7620 \\
\hline Air X & $1.08 \mathrm{~m} 2$ & 1.33 & 19.3 & 37.4 & 50.5 & 73.0 & 104 & 133 & 162 & 205 & 376 \\
\hline
\end{tabular}

Table 14. AEO from swept area with $12 \%$ efficiency

From this table we can see that an assumed efficiency of $12 \%$ would necessitate the use of multiple turbines in certain wind classes, and would necessitate the use of multiple turbines in any of the available wind classes for the Air $X$ to satisfy our functional unit. However, it should again be noted that in some cases the average wind speeds in the lower wind classes are actually below the cut-in wind speed of the turbines. Taking this into account, in most wind classes where the turbines could actually produce electricity they are fully capable of producing enough or more electricity to satisfy our functional unit. This loss of efficiency would also have a significant effect on the energy payback period and LCOE, making the turbines less viable as alternatives to traditional energy sources. For this reason, proper planning and placement of the turbine is key, as this allows for the maximization of turbine efficiency. 


\section{Conclusion}

Being that this paper is primarily a study of the feasibility of small wind turbine application in rural Thailand, the most important factor for determining successful implementation of the turbines we have analyzed is the LCOE. LCOE in turn is highly dependent on the wind class in which the turbine will be operating. The most common wind classes in terms of land area (see Appendix) in Thailand are 1.1 and 1.2, which both have little to no advantage over diesel generators in terms of LCOE. In wind classes 1.3 and 1.4, the economic advantages of wind power generation begin to emerge, but these are not pronounced until wind speeds are in wind class 2 (between 4.1 and $5 \mathrm{~m} / \mathrm{s}$ at $10 \mathrm{~m}$ elevation). This wind speed category is only found over large, cohesive areas in the south of Thailand, as are the rest of the higher wind classes. This means that the majority of rural Thais would not benefit economically from the use of small wind turbines without more government-driven incentives promoting wind turbine implementation. This might not be the case if people do not have access to the Thai grid and diesel prices increase. At present, less than $1 \%$ of Thailand's population does not have access to the grid, which has a much lower LCOE in the most common wind classes for all turbines analyzed. From the perspective of environmental impact, there are pronounced advantages to the implementation of wind turbines over the use of diesel generators or the Thai grid. However, because of the high cost of initial investment and the limited area in which turbines can be effectively utilized in Thailand, it is unlikely that many people will make the choice to invest in wind turbines for their personal or community-level electricity production. 


\section{References}

Alibaba. 2012a. "Yangzhou Hengdong Mechanical \& Electrical Co., Ltd." Alibaba.com. Accessed December 8. http://yzhd.en.alibaba.com/product/278787082-

209727621/DC_generator_2000W_Diesel_DC_Generator_Telecom_BTS_DC_generator_12V_24V_ 48V_DC_generator.html.

- - . 2012b. "Fuzhou Century Sea Power Co., Ltd." Alibaba.com. Accessed December 8. http://cncsc.en.alibaba.com/product/543668964213155144/Factory_price_2000w_diesel_generator.html.

- - . 2012c. "Factory Price!!! 5kva Diesel Generator." Alibaba.com. Accessed December 9. http://www.alibaba.com/product-gs/599429376/Factory_price_5kva_diesel_generator.html.

- - . 2012d. "2kw Portable Diesel Generator With 2 Wheels And Handles." Alibaba.com. Accessed December 9. http://www.alibaba.com/productgs/404579103/2kw_Portable_diesel_generator_with_2.html.

Alok Vasudev. 2012. "The Levelized Cost of Electricity." Accessed November 28. http://large.stanford.edu/courses/2010/ph240/vasudev1/.

Bengtsson, Selma, Karin Andersson, and Erik Fridell. 2011. Life Cycle Assessment of Marine Fuels - A Comparative Study of Four Fossil Fuels for Marine Propulsion. Chalmers University of Technology. http://www.dma.dk/themes/LNGinfrastructureproject/Documents/Fuels\%20and\%20environment/ LCA\%20of\%20four\%20possible\%20marine\%20fuels.pdf.

Better Generation Group Ltd. 2012. "Endurance S-343 5kW Wind Turbine." Better Generation. Accessed December 5. http://www.bettergeneration.co.uk/wind-turbine-reviews/endurance-s-343-5kwwind-turbine.html.

Chaichana, Tanate, and Sumpun Chaitep. "Wind power potential and characteristic analysis of Chiang Mai, Thailand." Journal of Mechanical Science and Technology. 24. no. 7 (2010): pp 1475-1479. www.springerlink.com/content/1738-494x (accessed November 16, 2012).

DEDE, . Ministry of Energy - Department of Alternative Energy, Development, and Efficiency, "Annual Report - Electric Power in Thailand 2011." Last modified 2011. Accessed November 1, 2012.

EPPO. 2012. "Retail Oil Prices." Energy Policy and Planning Office, Ministry of Energy, Thailand. Accessed November 30. http://www.eppo.go.th/retail_prices.html.

Fleck, Brian, and Marc Huot. 2009. "Comparative Life-cycle Assessment of a Small Wind Turbine for Residential Off-grid Use." Renewable Energy 34 (12) (December): 2688-2696. doi:10.1016/j.renene.2009.06.016.

Fullriver Battery. 2012. "DC Series." Fullriver. Accessed December 2. http://www.fullriver.com/products/dclist.htm.

GHK. 2006. Costs and Benefits of the ELV Directive - Final Report. European Commission. http://ec.europa.eu/environment/waste/pdf/study/final_report.pdf. 
Gipe, Paul. Wind Power: Renewable Energy for Home, Farm, and Business. White River Junction, VT: Chelsea Green Publishing Company, 2004.

Hammond, Geoff, and Craig Jones. 2008. Inventory of Carbon \& Energy (ICE). University of Bath. http://perigordvacance.typepad.com/files/inventoryofcarbonandenergy.pdf.

Hardy Diesel. 2012. "Fuel Burn Calculator." Hardy Diesel Generators. Accessed December 8. http://www.hardydiesel.com/generator-fuel-consumption-calculator.html.

InvertersRUs. 2012. "Power Bright 2300 Watt Power Inverter." InvertersRUs. Accessed December 9. http://www.invertersrus.com/powerbrightpw2300-12.html.

Jamil, M, S Parsa, and M Majidi. "Wind Power Statistics and an Evaluation of Wind Energy

Density."Renewable Energy. 6. no. 5 (1995): pp 623-628.

http://unc.summon.serialssolutions.com.libproxy.lib.unc.edu/ (accessed November 19, 2012).

Kabir, Md Ruhul, Braden Rooke, G.D. Malinga Dassanayake, and Brian A. Fleck. 2012. "Comparative Life Cycle Energy, Emission, and Economic Analysis of 100 kW Nameplate Wind Power Generation." Renewable Energy 37 (1) (January): 133-141. doi:10.1016/j.renene.2011.06.003.

Major, Stuart, Terry Commins, and Annop Noppharatana. "Potential of wind power for Thailand: an assessment." Maejo International Journal of Science and Technology. no. 2 (2008): pp 255-266. www.mijst.mju.ac.th (accessed November 16, 2012).

NREL. 2012. "Levelized Cost of Energy Calculator." National Renewable Energy Laboratory. Accessed November 28. http://www.nrel.gov/analysis/Icoe_documentation.html.

PeakPowerTools. 2012a. "Diesel Generator Duro Power 6500 Diesel Generator with Electric Starter." Www.peakpowertools.com. Accessed December 9.

http://www.peakpowertools.com//ProductDetails.asp?ProductCode=GDP6500ED.

- - . 2012b. "Diesel Generator Duro Power 4000 Diesel Generator with Electric Starter." Www.peakpowertools.com. Accessed December 9. http://www.peakpowertools.com/DieselGenerator-Duro-Power-4000-Watt-Generator-p/gdp4000ed.htm.

- - . 2012c. "Diesel Generator Duro Power 7500 Diesel Generator with Electric Starter." Www.peakpowertools.com. Accessed December 9.

http://www.peakpowertools.com//ProductDetails.asp?ProductCode=GDP7500ED.

Pietersz, Graeme. 2012. “Discount Rate." Moneyterms. Accessed December 8. http://moneyterms.co.uk/discount-rate/.

Pricewaterhouse Coopers. 2012. Life Cycle Assessment of CFGF - Continuous Filament Glass Fibre Products. http://www.glassfibreeurope.eu/uploads/files/LCA-report.pdf.

Rantik, Michail. " http://www.kfb.se/pdfer/M-99-28.pdf ." Kommunikations Forsknings Beredningen. . http://www.kfb.se/pdfer/M-99-28.pdf (accessed November 25, 2012). 
Sheehan, John, Vince Camobreco, James Duffield, Michael Graboski, and Housein Shapouri. 1998. Life Cycle Inventory of Biodiesel and Petroleum Diesel for Use in an Urban Bus. NREL. http://www.nrel.gov/docs/legosti/fy98/24089.pdf.

Skarvelis-Kazakos, S., L.M. Cipcigan, and N. Jenkins. 2009. "Micro-generation for 2050: Life-cycle Carbon Footprint of Micro-generation Sources." In Universities Power Engineering Conference (UPEC), 2009 Proceedings of the 44th International, 1 -5.

Solardyne. 2012. "AIR X Wind Generator 400 Watts." Solardyne.com. Accessed December 5. http://www.solardyne.com/air403wingen.html.

Spath, Pamela L., and Margaret K. Mann. 2011. Life Cycle Assessment of a Natural Gas Combined-Cycle Power Generation System. NREL. http://www.nrel.gov/docs/fy00osti/27715.pdf.

Spath, Pamela L., Margaret K. Mann, and Dawn R. Kerr. 1999. Life Cycle Assessment of Coal-fired Power Production. NREL. http://efile.mpsc.state.mi.us/efile/docs/16077/0065.pdf.

Sullivan, J., and L. Gaines. "A Review of Battery Life-Cycle Analysis: State of Knowledge and Critical Needs." Argonne National Laboratory. . http://www.transportation.anl.gov/pdfs/B/644.PDF

Sunpower Corporation. 2008. The Drivers of the Levelized Cost of Electricity for Utility-Scale Photovoltaics.

http://us.sunpowercorp.com/cs/Satellite?blobcol=urldata\&blobheadername1=ContentType\&blobheadername2=Content-

Disposition\&blobheadervalue1=application\%2Fpdf\&blobheadervalue2=inline\%3B+filename\%3DTh e\%2BDrivers\%2Bof\%2BLevelized\%2BCost\%2Bof\%2BElectricity\%2Bfor\%2BUtilityScale\%2BPhotovoltaics.pdf\&blobkey=id\&blobtable=MungoBlobs\&blobwhere $=1300258515050 \& s s$ binary=true.

The Home Depot. 2012. "Sportsman 2000 Peak Watt Portable Generator." The Home Depot. Accessed December 9. http://www.homedepot.com/h_d1/N-5yc1v/R100637533/h_d2/ProductDisplay?catalogld=10053\&langld $=-$ $1 \&$ keyword=diesel+generator\&storeld=10051\#.UMR0CYa8DPp

Unchai, Thitipong, Adun Janyalertadun, and Arne Hold. "Wind Energy Potential Assessment as Power Generation Source in Ubonratchathani Province, Thaialnd." Wind Engineering. 36. no. No 2 (2012): pp 131-144. http://unc.summon.serialssolutions.com.libproxy.lib.unc.edu/ (accessed November 16, 2012).

Waewsak, Jompob, Chana Chancham, and Y. Tirawanichakul. "The Near-Shore Wind Resource Assessment and Power Generation at Huasai, Nakhon Si Thammarat, Southern Thailand." (2011). http://www.chem.eng.psu.ac.th/tiche2011/TCHE/data/international/es.html (accessed November 16, 2012).

WTIC. 2012. "WTIC Prices." Wind Turbine Industries Corp. Accessed November 28. http://www.windturbine.net/prices.htm. 